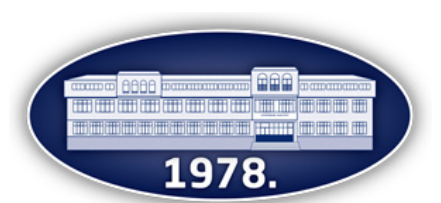

Publisher: Faculty of Agronomy Čačak

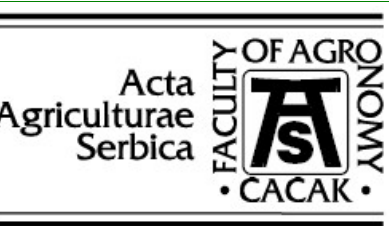

\title{
Occurrence of oxidative stress in sheep during different pregnancy periods
}

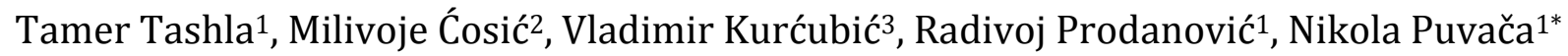 \\ 1 Department of Engineering Management in Biotechnology, Faculty of Economics and Engineering Management, \\ Business Academy University, Cvećarska 2, 21000 Novi Sad, Serbia \\ 2 Faculty of Agriculture, Bijeljina University, Pavlovića put bb, 76300 Bijeljina, Bosnia and Herzegovina \\ 3 Department of Food Technology, Faculty of Agronomy Čačak, University of Kragujevac, Cara Dušana 34, 32102 Čačak, \\ Serbia \\ *Corresponding author: nikola.puvaca@fimek.edu.rs
}

Received 13 May 2021; Accepted 16 September 2021

\begin{abstract}
A B S T R A C T
The objective of this paper was to evaluate oxidative stress during different pregnancy stages in Lohi sheep reared in Libya. Investigations were carried out on Lohi sheep between 1.5 and 5 years of age. A total of 40 sheep were sub-grouped into various stages of pregnancy along with non-pregnant controls as follows: non-pregnant $(n=10)$, early pregnancy ( $n=10)$, mid pregnancy $(\mathrm{n}=10)$, and late pregnancy $(\mathrm{n}=10)$. Blood samples were collected from pregnant sheep and preserved at $-20^{\circ} \mathrm{C}$ and further used for evaluating the concentrations of total antioxidant status (TAS), total oxidant status (TOS), malondialdehyde (MDA), superoxide dismutase (SOD), catalase (CAT), and paraoxonase (PON-1). In pregnant sheep, TAS, TOS, MDA, SOD, CAT, and PON-1 values were significantly $(P<0.05)$ different. TOS and MDA increased from non-pregnant ewes to early, mid and late stages of pregnancy whereas TAS, SOD, CAT, and PON-1 significantly $(P<0.05)$ decreased with the progression of pregnancy. The study suggests that the use of oxidant and antioxidant markers along with the blood metabolic profile should be the recommended procedure for monitoring health status during pregnancy to evade reduced productive performance and economic losses.
\end{abstract}

Keywords: stress, sheep, pregnancy, antioxidant status, superoxide dismutase, malondialdehyde.

\section{И 3 В $о$ Д}

Циљ рада је био да се испита оксидативни стрес током различитих стадијума бременитости код оваца расе Лохи у Либији. Испитивања су спроведена на овцама старости између 1,5 и 5 година. Укупно 40 оваца је груписано на основу различитих стадијума бременитости, заједно са контролном групом, коју чине овце које нису бремените. Групе су чиниле небремените овце $(\mathrm{n}=10)$, овце у раној бременитости $(\mathrm{n}=10)$, овце у средњој бременитости (n = 10) и овце у касном стадијуму бременитости $(\mathrm{n}=10)$. Узорци крви су прикупљени од свих оваца, конзервисани на $-20^{\circ} \mathrm{C}$ и даље коришћени за процену концентрације укупног антиоксидативног статуса (TAS), укупног оксидативног статуса (TOS), малондиалдехида (MDA), супероксид-дисмутазе (SOD), каталазе (CAT) и параоксоназа (PON-1). У TAS, TOS, MDA, SOD, CAT и PON-1 код бременитих оваца забележене су статистички значајне $(P<0,05)$ разлике у добијеним резултатима. Концентрације TOS и MDA су се повећавале од негравидних оваца до оваца у раној, средњој и касној фази бременитости, док су TAS, SOD, CAT и PON-1 забележили значајан пад $(P<0,05)$ са одмицањем гравидности. Може се закључити да употреба оксиданаса и антиоксиданаса као маркера заједно са метаболичким профилом у крви треба да се користи као препоручени поступак за праћење здравственог стања током периода бременитости како би се избегло смањење производних перформанси и економски губици.

Кључне речи: стрес, овце, бременитост, антиоксидативни статус, супероксид-дисмутаза, малондиалдехид.

\section{Introduction}

Free radicals are essentially unstable and reactive molecules formed as the by-products of oxidationreduction reactions and are categorized as reactive oxygen species (ROS) and reactive nitrogen species (RNS) (Boukhenouna et al., 2018). Generally, the development of ROS is equivalent to their removal and animals are in the status of oxidative balance (Taverne et al., 2018). An inequity or imbalance can arise whenever the formation of ROS increases or there is a decrease in the rate of their removal through antioxidant systems (Kostadinović et al., 2016; Puvača et al., 2016; Tashla, 2021). This condition is called oxidative stress (Gessner et al., 2017). Oxidative stress means the status of oxidative overload, whether this term is used for the cell, organ or organism (Kryl'skii et al., 2019). Due to oxidative stress, the structure and functions of lipids, proteins, nucleic acids, and enzymes are damaged and consequently cause tissue damage (Barati et al., 2020). The oxidative damage of lipids through ROS is typically produced during various 
physiological statuses in a balanced, suitable amount of these radicals and is an adaptive defense against stress (Burgos-Morón et al., 2019). However, lipid peroxidation in excess is critical and initiates a selfstimulating chain reaction and consequently releases malondialdehyde (MDA) as a degradation by-product and is a crucial indicator of pro-oxidant evaluation of oxidative stress (Puvača et al., 2016; Beit-Hallahmi, 1972). Oxidative stress study is imperative in evaluating homeostasis disturbances and production in farm animals (Sinha et al., 2020). It is immensely hazardous because it does not reveal any symptoms and is identifiable with immense difficulty by various methods of analysis of antioxidant defense elements and products of oxidative stress in terms of ROS (Kostadinović et al., 2016; Tashla et al., 2019). Oxidative stress is a new field used to evaluate metabolic imbalances in farm animals for better maintenance and production of these animals. Very few conditions or statuses have been studied for determining the influence of oxidative stress in sheep when homeostasis is disturbed (Cao et al., 2020). There may be an imbalance in oxidative status during various physiological conditions like pregnancy (Cecchini et al., 2019), parturition (Alharthi et al., 2018), and lactation (Masters, 2018). Pregnancy is associated with dynamic fluctuations in metabolic activities, resulting in enhanced basal oxygen consumption and energy requirement (Lewis et al., 2020). Not only are appropriate hormones required for the establishment of the placenta, but extra nutrients are also needed for the development and growth of the fetus (Limesand et al., 2018). Thus, mother's reserves for nutrients are now mobilized to meet the demand, and consequently, the formation of ROS is enhanced, and both the fetus and the mother are facing oxidative stress. Negative energy balance is evident during late pregnancy, which consequently leads to oxidative stress, enhanced lipid peroxidation, and lowered activity of antioxidants (Kalyesubula et al., 2019). The National Research Council (NRC) has approved approximately 1.5 times more energy requirement of ewes for maintaining homeostasis in late pregnancy (Zhang et al., 2018). During parturition, the mother's physical attempt for fetus removal and hormones are the cause of metabolic imbalance and excess development of ROS. Increased demands for energy during early lactation initiate oxidative reactions, and electron flow increases, thus inducing ROS formation (Mavangira and Sordillo, 2018). For many centuries, sheep have been used for milk, meat, skin, fiber, manure, and physical work in different conditions (Tasić, 2018; Obućinski et al., 2019; Stojiljković et al., 2019). Some landless farmers in tropical arid areas keep sheep for personal use and sale. Sheep are very important due to their biological factors such as short generation interval, twinning, and short growth periods, and they do not require much space. Among various sheep breeds, the Lohi breed is famous for its high-quality meat and high growth rate and maximum income achieved through lamb production. It has a large and massive body with an average weight of 45-62 kg. Body color is white with a dark brown head, and drooping ears and tail are heavy and small. Lohi sheep account for $40 \%$ of national sheep production. Oxidative stress determination is the best tool for improved reproductive performance in sheep (El-Ratel et al., 2020) and cows (Majkić et al., 2017). As no significant information is available in the literature on Lohi sheep [48] on the physiological biomarkers concerning pregnancy and production at different stages, it is being hypothesized that these biomarkers during different stages of pregnancy and production will behave quite differently.

The paper aimed to evaluate oxidative stress during different pregnancy stages in Lohi sheep reared in Libya.

\section{Materials and methods}

A biological experiment with sheep was performed following the EU legislation and the Three Rs principle under the Directive 2010/63/EU.

\subsection{Materials}

All sheep selected for the investigations were healthy and cared for following all animal welfare standards. Early pregnant animals were fed alfalfa hay, corn silage, and concentrate; however, late pregnant animals were offered grass hay, wheat straw, corn, alfalfa, soybean, and wheat flour. The animals were given fresh clean water twice a day. All the animals were vaccinated as per the schedule and treated with antihelminthics after six months.

Clinically normal and healthy Lohi sheep aged 1.55 years were selected for the present study. Each group of animals was sub-grouped according to the stage of pregnancy into non-pregnant animals (control), early pregnant animals (40-50 days), mid pregnant animals (60-90 days), and late pregnant animals (100 days onward).

\subsubsection{Blood sampling}

Veterinarians were engaged in blood sampling during the studied period. Early morning blood samples were taken aseptically from the jugular vein from each animal at different stages of their pregnancy in the volume of $5 \mathrm{ml}$ for EDTA-K2 and $5 \mathrm{ml}$ for clotting.

Blood samples with anticoagulant and without anticoagulant were used for biochemical analysis.

The samples without anticoagulants were centrifuged at $167 \times \mathrm{g}$ for 15 minutes. The serum was harvested and preserved at $-20{ }^{\circ} \mathrm{C}$ in small aliquots until further analysis in an accredited laboratory.

\subsubsection{Biochemical analysis}

To evaluate TAC, a semi auto-analyzer (Biosystems, BTS-330) was used for the spectrophotometric study. Monochromatic light (660nm wavelength) was selected from the spectrophotometer and used to heat the selected filter for about $5 \mathrm{~min}$. Two hundred $\mu \mathrm{l}$ reagent was mixed with $5 \mu \mathrm{L}$ serum/samples/standards. The first reading was taken before mixing reagent I with reagent II, which was used as a blank. Thereafter, $20 \mu \mathrm{L}$ reagent II was added to the above mixture. This mixture was now incubated at $37^{\circ} \mathrm{C}$ for $5 \mathrm{~min}$, and the second absorbance was read. Using the standard curve against the standards, delta absorbance was used to calculate TAC.

The oxidants present in the samples caused the oxidization of the 0-dianisidine complex into ferric ion. Glycerol was used in this mixture to accelerate the reaction. Xylenol orange in the acidic medium formed a 
colored complex with ferric ions. The spectrophotometer was used to study color intensity, i.e. for the direct measurement of sample's oxidant molecules. Water was used for calibration purposes, and results were shown as $\mu \mathrm{mol} \mathrm{H}_{2} \mathrm{O}_{2}$ equiv. $\mathrm{L}^{-1}$. The assay was sensitive at $1.13 \mu \mathrm{mol} \mathrm{H}_{2} \mathrm{O}_{2}$ equiv. $\mathrm{L}^{-1}$, along with a precision rate less than $3 \%$ and linearity was shown to be $200 \mu \mathrm{mol} \mathrm{H}_{2} \mathrm{O}_{2}$ equiv. $\mathrm{L}^{-1}$. Serum samples in aliquots of $35 \mu \mathrm{l}$ were added into $225 \mu \mathrm{l}$ reagent I, and the first absorbance was taken immediately. An 11 $\mu \mathrm{l}$ aliquot of reagent II was mixed in this serum sample and reagent I mixture, and after 4 minutes, final absorbance was read. Bichromatic wavelength containing main/primary $560 \mathrm{~nm}$ and $800 \mathrm{~nm}$ secondary/differential wavelengths was used for absorbance. The actual concentration of $\mu \mathrm{mol} \mathrm{H}_{2} \mathrm{O}_{2}$ equiv. $\mathrm{L}^{-1}$ was calculated from the standard curve by using delta change in absorbance.

MDA was measured by the lipid peroxidation (LPO; $\mu$ mol L ${ }^{-1}$ ) method. Kits (Abacum, UK) were equipped with components and instructions for their use and storage. LPO assay FTS reagent I, LPO assay FTS reagent II, lipid hydroperoxide standard, LPO Assay Extract R, and LPO assay Triphenylphosphine were prepared by using one vial of each component and stored as per instructions. Before initiating the LPO estimation method, lipid hydroperoxidase was extracted to form chloroform. One ml final volume of the assay was attained in each test tube. According to the instructions in the protocol, standards were run with each test simultaneously and in triplicate.

The method of Kostadinović et al. (2016) was used for the determination of serum SOD activity. Xanthine oxidase was employed to produce superoxide flux. Nitroblue tetrazolium (NBT) was used as an indicator of superoxide production. The degree of inhibition of the reaction unit of the enzyme was used to determine SOD activity, which would cause $50 \%$ inhibition for the reduction of NBT. Results were expressed in $\mu \mathrm{mL}^{-1}$. To prepare 0.052 sodium pyrophosphate buffer, $2.32 \mathrm{~g}$ sodium pyrophosphate was dissolved in $80 \mathrm{~mL}$ distilled water, and was adjusted to 8.3 by adding $1 \mathrm{~N} \mathrm{HCL} \mathrm{pH,}$ then the volume was made up to $100 \mathrm{~mL}$ by distilled water and it was preserved at $4^{\circ} \mathrm{C}$. For the preparation of $186 \mu \mathrm{M}$ phenazinemethosulphate solution, 5.697924 mg phenazinemethosulphate was dissolved in $100 \mathrm{~mL}$ of distilled water. To prepare $300 \mu \mathrm{M}$ nitrobluetetrazolium solution, $24.5292 \mathrm{mg}$ nitrobluetetrazolium was dissolved in $100 \mathrm{~mL}$ of distilled water. To prepare $780 \mu \mathrm{M}$ NADH solution, $51.74754 \mathrm{mg}$ NADH was dissolved in $100 \mathrm{~mL}$ of distilled water. A total of $500 \mu \mathrm{L}$ serum was added into $500 \mu \mathrm{L}$ ethanol and $300 \mu \mathrm{L}$ chloroform and centrifuged for half an hour at $18000 \times$ g. A total of $900 \mu \mathrm{L}$ SOD reagent was prepared by mixing $0.1 \mathrm{mmol} / \mathrm{L}$ xanthine + $0.1 \mathrm{mmol} / \mathrm{L}$ ethylene diamine tetraacetic acid (EDTA) + $25 \mathrm{mmol} / \mathrm{L}$ nitro blue tetrazolium (NBT) + $50 \mathrm{mg}$ serum (BSA) and $40 \mathrm{mmol} / \mathrm{L} \mathrm{Na}_{2} \mathrm{CO}_{3}$ maintained at $\mathrm{pH}$ 10.2. The reagent was mixed with $50 \mu \mathrm{L}$ of the supernatant removed after centrifugation, and incubation was done at $25^{\circ} \mathrm{C}$ for $20 \mathrm{~min}$. By adding 1 $\mathrm{mL} \mathrm{CuCl}_{2}(0.8 \mathrm{mmol} / \mathrm{L})$, the reaction was stopped, and the absorbance of samples was read at $560 \mathrm{~nm}$.

A spectrophotometer assay based on $\mathrm{H}_{2} \mathrm{O}_{2}$ was used to analyze catalase activity by Kostadinović et al. (2016) methodology. One $\mathrm{ml}$ substrate was prepared by mixing $65 \mu \mathrm{mol} \mathrm{mL}-1 \mathrm{H}_{2} \mathrm{O}_{2}$ dissolved in $60 \mathrm{mmol} \mathrm{L}^{-1}$ sodium potassium buffer ( $\mathrm{pH}$ 7.4). Incubation of $0.2 \mathrm{~mL}$ serum along with $1.0 \mathrm{~mL}$ substrate was done at $25^{\circ} \mathrm{C}$ for $1 \mathrm{~min}$. The linearity of serum catalase was up to 100 $\mathrm{KU} \mathrm{L}^{-1}$. However, when catalase activity increased from $100 \mathrm{KU} \mathrm{L}^{-1}$, phosphate buffer was diluted from 2 to 10 fold, and the assay was repeated. Under these circumstances, 1 unit catalase produced $1 \mu \mathrm{mol} \mathrm{mL}-1$ $\mathrm{H}_{2} \mathrm{O}_{2} \mathrm{~min}^{-1}$. The addition of $1.0 \mathrm{ml}$ of $32.4 \mathrm{mmol} \mathrm{L}^{-1}$ ammonium molybdate $\left[\left(\mathrm{NH}_{4}\right)_{6} \mathrm{M}_{0} \mathrm{O}_{24} .4 \mathrm{H}_{2} \mathrm{O}\right]$ reaction was stopped by the production of yellow complex and this complex was read at $405 \mathrm{~nm}$ against blank 3 .

Paraoxonase enzyme has the phenotypes PON-I, PON-II, and PON-III, with PON-I as the most active. PON I hydrolyzes several types of organophosphates such as paraoxon, aromatic esters such as phenylacetate, and lipid peroxidation products, and also reduces their accumulation. The rate of paraoxon enzymatic hydrolysis into p-nitrophenol was used to estimate PON I activity. A spectrophotometer was used to determine the color formed because of p-nitrophenol production. The primary hydrolysis rate or sensitivity of hydrolysis was constant until $5 \mathrm{~min}$.

\subsection{Statistical analysis}

The data obtained were subjected to one-way analysis of variance (ANOVA) techniques. The data were analyzed by using the STATISTICA 13 statistical software. Duncan's Multiple Range test was applied to explain the significant difference between the stages of pregnancy.

\section{Results and discussion}

The results of oxidative stress evaluation are shown in Table 1. The total antioxidant status of Lohi sheep was observed by two-way ANOVA and the results showed significant $(P<0.05)$ differences. Lohi sheep exhibited a decrease in TAS concentration from non-pregnant to all subsequent stages, although only non-pregnant and advanced pregnant ewes were statistically different $(P<0.05)$. Lohi sheep showed higher values of TAS concentration through all stages. Findings have shown a significant decrease in TAS concentration from non-pregnant to advanced pregnant stages in sheep; however, significant results were given by non-pregnant and late pregnant ewes (Nawito et al., 2016). A new method to develop and evaluate TAS in animals was developed. Similar results were obtained by other studies, where the TAC value was highest in dry ewes and decreased with pregnancy progression (Nawito et al., 2016). As pregnancy is a stressful physiological condition, it causes an increase in cortisol concentration. The decrease in TAS might coincide with the absence of vitamins and mineral supplementation, i.e., exogenous antioxidants, during pregnancy. Similar results in reducing TAS during pregnancy were confirmed by different researchers (Nawito et al., 2016). Groups of sheep at various pregnancy stages showed significantly different results $(P<0.05)$ regarding the total oxidant status (TOS). The total oxidant status concentration increased from the first stage of non-pregnant animals to advanced pregnancy in the ewes. However, significantly $(P<$ 0.05 ) different results were observed in mid and advanced pregnancy animals in ewes.

Similarly, TAS activity decreased just before parturition. TAC decreased during pregnancy as compared to non-pregnant groups. The oxidative stress 
index (OSI), described as the ratio of TOS/TAS (Figure 1), increased from dry to pregnant animals at all stages of pregnancy; this confirmed our results for TOS increase and TAS decrease.

Table 1.

Evaluation of oxidative stress parameters during pregnancy stages in Lohi sheep

\begin{tabular}{ccccccc}
\hline Stages of & \multicolumn{5}{c}{ Biochemical blood parameters } \\
\cline { 2 - 7 } pregnancy & TAS & TOS & MDA & SOD & CAT & PON-1 \\
\hline Non & $1.93 \pm 0.02 \mathrm{a}$ & $0.48 \pm 0.01 \mathrm{c}$ & $0.79 \pm 0.03 \mathrm{~d}$ & $3.35 \pm 0.06 \mathrm{a}$ & $3.30 \pm 0.07 \mathrm{a}$ & $213.20 \pm 1.17 \mathrm{a}$ \\
Early & $1.73 \pm 0.02 \mathrm{~b}$ & $0.52 \pm 0.01 \mathrm{c}$ & $1.75 \pm 0.06 \mathrm{c}$ & $2.85 \pm 0.07 \mathrm{~b}$ & $2.84 \pm 0.11 \mathrm{~b}$ & $199.70 \pm 1.19 \mathrm{~b}$ \\
Mid & $1.67 \pm 0.01 \mathrm{~b}$ & $0.64 \pm 0.01 \mathrm{~b}$ & $2.11 \pm 0.08 \mathrm{~b}$ & $2.40 \pm 0.08 \mathrm{c}$ & $2.43 \pm 0.09 \mathrm{c}$ & $178.00 \pm 1.33 \mathrm{c}$ \\
Advanced & $1.22 \pm 0.01 \mathrm{~d}$ & $1.23 \pm 0.04 \mathrm{a}$ & $2.60 \pm 0.05 \mathrm{a}$ & $1.78 \pm 0.08 \mathrm{~d}$ & $1.80 \pm 0.03 \mathrm{~d}$ & $171.10 \pm 1.89 \mathrm{~d}$ \\
\hline
\end{tabular}

TAS - total antioxidant status; TOS - total oxidant status; MDA - malondialdehyde; SOD - superoxide dismutase; CAT - catalase; PON-1 - paraoxonase. a-d - the rows showing the same letters do not differ significantly $(P<0.05)$.

Ewes at various stages of pregnancy exhibited significantly $(P<0.05)$ different results in serum MDA levels. The serum malondialdehyde concentration in Lohi sheep showed a significant $(P<0.05)$ increase from non-pregnant to advanced pregnancy stages. The likely cause of this rise in MDA concentration could be an overproduction of free radicals (ROS) and induction of lipid peroxidation. The other reason for the steady increase in MDA concentration with the progression of pregnancy was related to decreased levels of total antioxidant capacity (TAC), antioxidant enzymes, i.e., catalase (CAT), and superoxide dismutase (SOD).

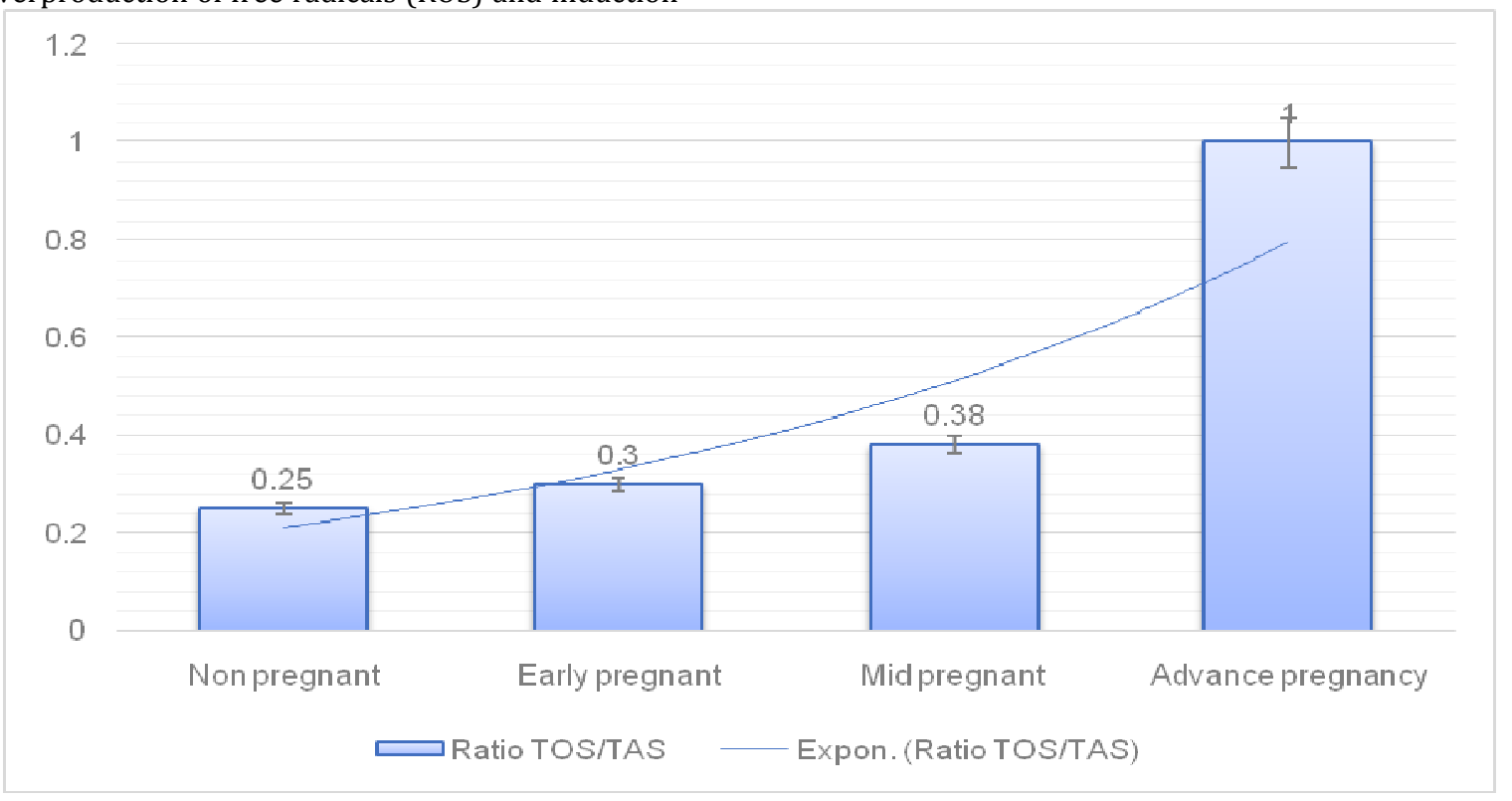

Figure 1. Oxidative stress index (OSI) as a marker of oxidative stress (TOS/TAS)

This has also been proved by our findings of decreased levels of TAC, SOD and CAT enzymes with the advancement of pregnancy. The serum superoxide dismutase concentration was significantly decreased from non-pregnant animals throughout pregnancy. Our results are consistent with the studies reporting a decrease in SOD activity from non-pregnant ewes to the end of pregnancy, i.e., the first day before lambing. Ewes showed a predisposition to oxidative stress in the second to third months of pregnancy. Our results showed significant changes in redox status indicators, denoting an increase in oxidative stress. While reactive oxygen species, i.e., superoxide anion radical were formed in the organism, SOD transformed these into hydrogen peroxide through the dismutation process. Consequently, this decrease in lipid peroxide concentration is probably linked to a reduction in SOD activity. Our results were consistent with the findings which indicated a decrease in SOD concentration in pregnant sheep irrespective of high or low energy diets.

Catalase concentration significantly decreased from non-pregnant to different stages of pregnancy in sheep. Our results are consistent with other reports showing decreased catalase activity from non-pregnant to early, mid and advanced pregnancy stages in ewes (Gür et al., 2011). Another study of the effect of pregnancy and nutrition in pregnant sheep resulted in a decreased CAT level (Dias e Silva et al., 2016). In our research, the observed decrease in antioxidant enzymes might be due to the fact that superoxide radical was converted into hydrogen peroxide and oxygen by means of SODs, while the CAT and peroxidases converted hydrogen peroxide into water. Thus, both of these toxic species, hydrogen peroxide and superoxide radical, transformed into water.

PON-I concentration had significantly $(P<0.05)$ different values, which were the highest in nonpregnant animals, but significantly decreased in early, mid and advanced pregnancy animals. PON-I acts as an antioxidant enzymatic defense enzyme against lipid hydroperoxides and lipid peroxides in low density lipoprotein (LDL) (Turk et al., 2008). According to our results, there was a significant decrease in paraoxonase concentration with pregnancy progression in sheep 
groups. Non-pregnant animals had the maximum value of paraoxonase in our results. However, there is little information about serum PON-I activity in veterinary medicine, and scarce knowledge about the relationship between PON-I and arylesterase activity during reproductive performance and during lactation in sheep (Kanakkaparambil et al., 2009).

\section{Conclusions}

Prooxidant or antioxidant statuses and biochemical parameters are considered useful tools for evaluating oxidative stress during the physiological stress conditions of sheep pregnancy. Additionally, these tools might be helpful for improved management strategies under farm conditions in ewes. Animals face oxidative stress as indicated through an increase in the prooxidants MDA and TOS and a decrease in antioxidant capacity TAS, SOD, CAT, and PON-I with pregnancy progression. The use of oxidant and antioxidant markers and blood metabolic profiles is the recommended procedure for monitoring health status during this critical period and avoiding reduced productive performance and economic losses.

\section{Acknowledgment}

This research was a part of the $\mathrm{PhD}$ thesis by Tamer Tashla, entitled "Oxidative stress during pregnancy and lactation of Lohi sheeps".

\section{Declaration of competing interest}

Authors declare no competing interest.

\section{References}

Alharthi, A., Zhou, Z., Lopreiato, V., Trevisi, E., Loor, J.J. (2018) Body condition score prior to parturition is associated with plasma and adipose tissue biomarkers of lipid metabolism and inflammation in Holstein cows. Journal of Animal Science and Biotechnology, 9(12).

Barati, E., Nikzad, H., Karimian, M. (2020). Oxidative stress and male infertility: Current knowledge of pathophysiology and role of antioxidant therapy in disease management. Cellular and Molecular Life Sciences, 77, 93-113.

Beit-Hallahmi, B. (1972). Developing the prison fantasy questionnaire (PFQ). Journal of Clinical Psychology, 28, 551-554.

Boukhenouna, S., Wilson, M.A., Bahmed, K., Kosmider, B. (2018). Reactive oxygen species in chronic obstructive pulmonary disease. Oxidative Medicine and Cellular Longevity, 1-9.

Burgos-Morón, E., Abad-Jiménez, Z., Martínez de Marañón, A., Iannantuoni, F., Escribano-López, I., López-Domènech, S., Salom, C., Jover, A., Mora, V., Roldan, I., Solá, E., Rocha, M., Víctor, V.M. (2019). Relationship between oxidative stress, ER stress, and inflammation in type 2 diabetes: The battle continues. Journal of Clinical Medicine, 8, 1385.

Cao, C., Zhang, H., Wang, K., Li, X. (2020). Selenium-rich yeast mitigates aluminum-mediated testicular toxicity by blocking oxidative stress, inhibiting NO production, and disturbing ionic homeostasis. Biological Trace Element Research, 195, 170-177.

Cecchini, S., Fazio, F., Bazzano, M., Caputo, A.R., Giannetto, C., Piccione, G. (2019). Redox status and oxidative stress during late pregnancy and postpartum period in mares. Livestock Science, 230, 103821.
Dias e Silva, T.P., Costa Torreão, J.N. da., Torreão Marques, C.A., de Araújo, M.J., Bezerra, L.R., kumar Dhanasekaran, D., Sejian, V. (2016). Effect of multiple stress factors (thermal, nutritional and pregnancy type) on adaptive capability of native ewes under semi-arid environment. Journal of Thermal Biology, 59, 39-46.

El-Ratel, I.T., Abdel-Khalek, A.E., Gabr, S.A., Hammad, M.E., El-Morsy, H.I. (2020). Influence of allicin administration on reproductive efficiency, immunity and lipid peroxidation of rabbit does under high ambient temperature. Journal of Animal Physiology and Animal Nutrition, 104, 539-548.

Gessner, D.K., Ringseis, R., Eder, K. (2017). Potential of plant polyphenols to combat oxidative stress and inflammatory processes in farm animals. Journal of Animal Physiology and Animal Nutrition, 101, 605-628.

Gür, S., Türk, G., Demirci, E., Yüce, A., Sönmez, M., Özer, Ș., Aksu, E. Effect of pregnancy and foetal number on diameter of corpus luteum, maternal progesterone concentration and oxidant/antioxidant balance in ewes: Pregnancy affects maternal oxidative stress. Reproduction in Domestic Animals, 46, 289-295.

Kalyesubula, M., Rosov, A., Alon, T., Moallem, U., Dvir, H. (2019). Intravenous infusions of glycerol versus propylene glycol for the regulation of negative energy balance in sheep: A randomized trial. Animals, 9, 731.

Kanakkaparambil, R., Singh, R., Li, D., Webb, R., Sinclair, K.D. (2009). B-Vitamin and homocysteine status determines ovarian response to gonadotropin treatment in sheep. Biology of Reproduction, 80, 743-752.

Kostadinović, Lj., Popović, S., Puvača, N., Čabarkapa, I., Kormanjoš, Š., Lević, J. (2016). Influence of Artemisia absinthium essential oil on antioxidative system of broilers experimentally infected with Eimeria oocysts. Veterinarski arhiv, 86, 253-264.

Kryl'skii, E.D., Popova, T.N., Safonova, O.A., Stolyarova, A.O., Razuvaev, G.A., de Carvalho, M.A.P. (2019). Transcriptional regulation of antioxidant enzymes activity and modulation of oxidative stress by melatonin in rats under cerebral ischemia. Reperfusion Conditions. Neuroscience, 406, 653-666.

Lewis, N., Hinrichs, K., Leese, H.J., Argo, C., Brison, D.R., Sturmey, R. (2020). Energy metabolism of the equine cumulus oocyte complex during in vitro maturation. Scientific Reports, 10, 3493.

Limesand, S.W., Camacho, L.E., Kelly, A.C., Antolic, A.T. (2018). Impact of thermal stress on placental function and fetal physiology. Animal Reproduction, 15, 886-898.

Majkić, M., Cincović, M., Belić, B., Plavša, N., Lakić, I., Radinović, M. (2017). Relationship between milk production and metabolic adaptation in dairy cows during heat stress. Acta Agriculturae Serbica, 22(24), 123-131.

Masters, D.G. (2018). Practical implications of mineral and vitamin imbalance in grazing sheep. Animal Production Science, 58, 1438.

Mavangira, V., Sordillo, L.M. (2018). Role of lipid mediators in the regulation of oxidative stress and inflammatory responses in dairy cattle. Research in Veterinary Science, $116,4-14$.

Nawito, M.F., Hameed, A.R.A.E., Sosa, A.S.A., Mahmoud, K.G.M. (2016). Impact of pregnancy and nutrition on oxidant/antioxidant balance in sheep and goats reared in South Sinai, Egypt. Veterinary World, 9, 801-805.

Obućinski, D., Prodanović, R., Ljubojević Pelić, D., Puvača, N. (2019). Improving competitiveness and sustainable approach to management in animal husbandry. Journal of Agronomy, Technology and Engineering Management, 2(1), 228-234.

Puvača, N., Kostadinović, Lj., Popović, S., Lević, J., Ljubojević, D., Tufarelli, V., Jovanović, R., Tasić, T., Ikonić, P., Lukač, D. (2016). Proximate composition, cholesterol concentration and lipid oxidation of meat from chickens fed dietary spice addition (Allium sativum, Piper nigrum, Capsicum annuum). Animal Production Science, 56, 19201927. 
Sinha, T., Naash, M.I., Al-Ubaidi, M.R. (2020). Flavins act as a critical liaison between metabolic homeostasis and oxidative stress in the retina. Frontiers in Cell and Developmental Biology, 8, 861.

Stoiljković, J., Stoiljković, Z., Vesković, S., Vanovac, J., Đukić, D. (2019). The influence of the length of fattening and gender of the lambs on the thickness of the subcutaneous fatty tissue. Acta Agriculturae Serbica, 24(48), 135-142.

Tashla, T., Puvača, N., Ljubojević Pelić, D., Prodanović, R., Bošković, J., Ivanišević, D., Jahić, M., Mahmoud, O., Giannenas, I., Lević, J. (2019). Dietary medicinal plants enhance the chemical composition and quality of broiler chicken meat. Journal of Hellenic Veterinary Medical Society, 70, 1823-1832.

Tashla, T. (2021). Oxidative stress during pregnancy and lactation of Lohi sheeps. PhD thesis, Faculty of Economics and Engineering Management in Novi Sad, University Business Academy in Novi Sad, 1-107.
Tasić, S. (2018). Geographical and economic performance of organic agriculture and its impact on the stability of gastronomy tourism in Serbia. Oditor, 4(1), 38-51.

Taverne, Y.J., Merkus, D., Bogers, A.J., Halliwell, B., Duncker, D.J., Lyons, T.W. (2018). Reactive oxygen species: Radical factors in the evolution of animal life: A molecular timescale from earth's earliest history to the rise of complex life. BioEssays, 40, 1700158.

Turk, R., Juretić, D., Gereš, D., Svetina, A., Turk, N., FlegarMeštrić, Z. (2008). Influence of oxidative stress and metabolic adaptation on PON1 activity and MDA level in transition dairy cows. Animal Reproduction Science, 108, 98-106.

Zhang, H., Zhao, F., Nie, H., Ma, T., Wang, Z., Wang, F., Loor, J.J. (2018). Dietary N-Carbamylglutamate and rumenprotected L-arginine supplementation during intrauterine growth restriction in undernourished ewes improve fetal thymus development and immune function. Reproduction, Fertility and Development, 30, 1522. 